\title{
Implementing Code Igniter Framework in Open Source Mobile Learning Application
}

\author{
Arief Hidayat \\ Information System Department \\ STIMIK Pro Visi \\ Semarang
}

\author{
Victor Gayuh Utomo \\ Computer Science Department \\ STIMIK Pro Visi \\ Semarang
}

\begin{abstract}
The concept of learning at any time and any place is unable to get fully implemented yet. The reason is that the currently available e-learning system requires a personal computer to access it. Moreover, users need to find convenient place to access the e-learning. In order to implement the concept, an applications of electronic distance learning that run on mobile device, such as cell phone, personnel digital assistant (PDA), or smart phone, is needed. The application is called mobile learning (m-learning). A different approach to design mlearning application is required due to the differences in mobile device and personal computer nature. This study implements Code Igniter (CI) framework that support modelview-controller (MVC) programming technique in order to decrease application development time. It may happen since Code Igniter provides a set of libraries that provides basic functionality to solve common problems. Using Code Igniter, developers no longer need to develop application from scratch and may directly focus on the codes that build m-learning application functionality.
\end{abstract}

\section{Keywords}

Code Igniter, mobile learning, open source

\section{INTRODUCTION}

The main disadvantage of conventional learning is the limitation of the available learning time. Learning activities have strong relation to the distribution and provision of class room and also teacher schedule. Since many stakeholders involve, especially teachers and students, learning activities need a shared commitment about time and place. The condition put constraints which limit the flexibility of time availability for learning activity [1].

Many developments happen in education nowadays, including the development of e-learning system. E-learning system is a technology that support distance learning, a learning system that can be taken from remote place and has no obligation for direct interaction between students and teachers. Rapid advance in the mobile and wireless communication technology give a big support for e-learning system. The combination creates new research field, named mobile learning (m-learning) [2].

Mobile learning is defined as a tool or service that provides general information to students electronically. Student is allowed to use mobile learning in order to access educational content which help to pursue knowledge without worrying the location and time [3]. Mobile learning system utilizes the mobility nature of handheld / mobile devices, such as mobile phones and personnel digital assistant (PDA), to provide a learning function at anyplace and any time.
The increasing number of wireless networks, types of services, and mobile devices is expected to encourage the development of m-learning systems in the future. Having a cell phone and a subscription to one of the mobile operators has become something that is affordable and often has become a way of life for people throughout the community. Moreover, mobile phone offers a more complete and sophisticated features and functions in a way that it is expected sometimes in the future mobile phone may be an alternative to the PC (Personal Computer). It is also supported by a faster network and connectivity that enables the interconnection of data and multimedia, no longer limited to voice and text, within higher data transfer rate.

While in e-learning user is required to deal with a personal computer connected to the Internet, m-learning allows an easier approach for the user to interact with the system. Mlearning is easy to carry anywhere, which offers portability; practical, since the student is no longer bothered with the tools being used; and easy to use, for people who don't really understand the technology. However, unlike e-learning which uses a PC that has a large enough computing capability, mlearning relies on mobile devices which have limited capabilities. The limitation cause m-learning application development needs to be designed in a particular way which is different from the general implementation of e-learning. Due to the limited computational capabilities, m-learning applications should be designed more optimum, more effective and efficient than applications designed for the PC.

Currently, some colleges are implementing distance learning system using electronic learning (e-learning). Under such system, student may access all learning materials (course) from outside of campus using a computer, and even exams are also available online. The minimum requirement for distance learning implementation is a set of computer or notebook to access the e-learning system. The concept of learning at any time and any place is unable to be fully implemented, as learning activities require the user to find a comfortable place to learn. Users are unable to access learning materials with practical, easy to use and easy to access. In order to achieve fully implemented distance learning, it is necessary to provide an application that enables learning any place and any time, using mobile devices such as mobile phone, PDA or Smart Phone, such as mobile learning.

In this study, the mobile learning application developed by implementing Code Igniter (CI) framework that support model-view-controller (MVC) programming technique in order to decrease application development time. It may happen since Code Igniter provides a set of libraries that provides basic functionality to solve common problems. Using Code Igniter, developers no longer need to develop application from scratch and may directly focus on the codes that build m-learning application functionality. 
Web application frameworks have technical and organizational advantages compared to classical development method, such as faster development and cleaner structure. Developers also tend to more comfortable in developing under web framework since they do not need to deal with many common programming tasks[4].

\section{MOBILE LEARNING}

Mobile learning or m-learning is often defined as an elearning which utilize mobile computing devices. Ally et al [5] defines m-learning as electronic learning materials that may be accessed at any time and any place in mobile computing devices. Usually, such mobile device in discussion is in the form of PDA and digital mobile phone. However, with many computing and/or communication device introduced lately, the device includes any devices which meet the following conditions, considerably small, autonomous work, keep in our touch for daily use and supporting some forms of learning. The small device behaves as a tool to access content which is stored locally in the device or makes a telecommunication connection to public content. Using the same device, interaction may be made through voice or message in the form of text, image or video.

Mobile learning (m-learning) can be referred as the usage of mobile and IT handheld devices such as PDAs, mobile phones, laptops and PC tablets both in teaching and learning [6]. As a learning system, m-learning is unique because students may access course content, counseling and courserelated applications from any place at any time. Using $\mathrm{m}$ learning, it is hoped that student put more attention to the course content; learning process becomes more interesting and motivating students for lifelong learning. Collaboration opportunity in ad hoc and informal interaction among student is higher in m-learning as opposed to conventional learning [7].

Based on research on m-learning projects in the UK, Italy and Sweden [8], the benefits of m-learning are ;

1. Provide learning truly at any place, any time, and personalized;

2. Makes learning more lively, or add variation to conventional teaching;

3. Eliminate some of the formalities that non-traditional student considers as not interesting or scary, and make the lesson more interesting;

4. Help deliver and support the learning of literacy, numeracy and language;

5. Bring facility for learning experience, both individually and collaboratively;

6. Help against the rejection of the use of ICT by providing a bridge between the less known to technology, using mobile phones, and PCs;

7. Has been observed can help young learners to remain more focused for longer periods of time;

8. Provide improvement on confidence and self-evaluation in education.

\section{PROGRAMMING MVC USING CI 3.1 Code Igniter}

Code Igniter (CI) is an application development framework which works under PHP platform, as a framework to work or develop a PHP program in a more systematic ways. Developers can directly and quickly produce programs, by following the framework provided by the CI. Programmers do not need to create a program from scratch, because the $\mathrm{CI}$ provides a set of libraries needed to accomplish common work, while keeping simple interface and logical structure to access its library. The programmer can focus on the code that must be made to complete a job. CI is a framework that has a free license to use, as it uses the open-source Apache license / BSD. CI was first developed by Rick Ellis [9].

\subsection{Model View Controller}

MVC (Model View Controller) programming technique is a currently popular programming technique, which expects to discipline programmer to divide the program into three parts as follows [9]:

1. Model

Models represent the things that users are browsing or editing. It may come in simple form, which merely hold data that's being transferred between controllers and views, or in sophisticated domain models that encapsulate the information, operations, and rules that are meaningful in the subject matter (business domain) of the application. Domain models describe the state of the application's universe at the present moment, but are totally disconnected from any notion of a UI.

2. View

Views describe how to render model objects as a visible UI, but otherwise contain no logic.

3. Controller

Controllers handle incoming requests, perform operations on the domain model, and choose a view to render back to the user.

While there are many variations on the MVC pattern, they all have the same primary goal: separation of concerns. By keeping a clear division between concerns, the application will be easier to maintain and extend over its lifetime, no matter how large it becomes.

CI is one of the PHP programming frameworks that have the ability to implement the MVC programming techniques.

\section{SYSTEM DEVELOPMENT METHOD}

M-learning application was developed under the ComputerBased Systems Engineering Method based on software engineering principles through the stages System Development Life Cycle (SDLC). SDLC is composed of Analysis, Design, Implementation, Testing, and Evaluation. These stages can be done in overlap and cyclical. The design phase consists of process modeling, data modeling, and design of the user interface.

Modeling process transforms business process into models. In m-learning application, it means creating model for administrator, teacher, and student by observe the learning process in which they involve. The models came in the form of diagram. In this study, two types of diagram are used, that are use case diagram and activity diagram. 
Administrator has the role as the manager of m-learning and solely responsible for the application. The diagram shows the functions needed by administrator in the m-learning applications. In order to perform its functions, an administrator needs to log in first into the application. Those functions are implemented in the following activities:

1. add, edit, and delete users,

2. add and edit user roles,

3. add, edit, and delete courses,

4. enroll student to courses,

5. add, view, and delete material,

6. add, edit, and delete news / announcements,

7. add, view, edit, and delete discussion,

8. add, edit, and delete tasks,

9. review and score task submission,

10. add, edit, and delete test,

11. review exam results,

12. add, edit, and delete exam questions

First step, an administrator has to do in managing m-learning system is to $\log$ in. Administrator opens web browser and write the address of m-learning. Administrator logs in to the system, by supplying username and address to the login menu. After system authenticate the login, administrator allowed to proceed to the system management. The activities included in system management are: add, view, edit, and delete. Administrators select the required menu such as manage users, manage user roles, manage course, manage content, manage news, manage discussions, and administer exams. Administrator activity is done when the logout link clicked.

\section{MODEL-VIEW-CONTROLLER IMPLEMENTATION}

Model View Controller architecture that has been created can be seen in Figure 1.

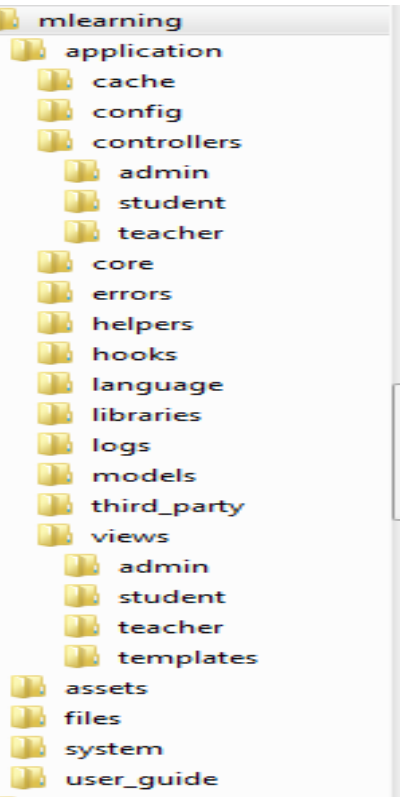

Fig 1: Code Igniter MVC Directory Structure
Based on Figure 1, most files needed by developer are provided by developer. Customization needed to build the mlearning application performed to files under three directories, i.e. models, views, and controllers.

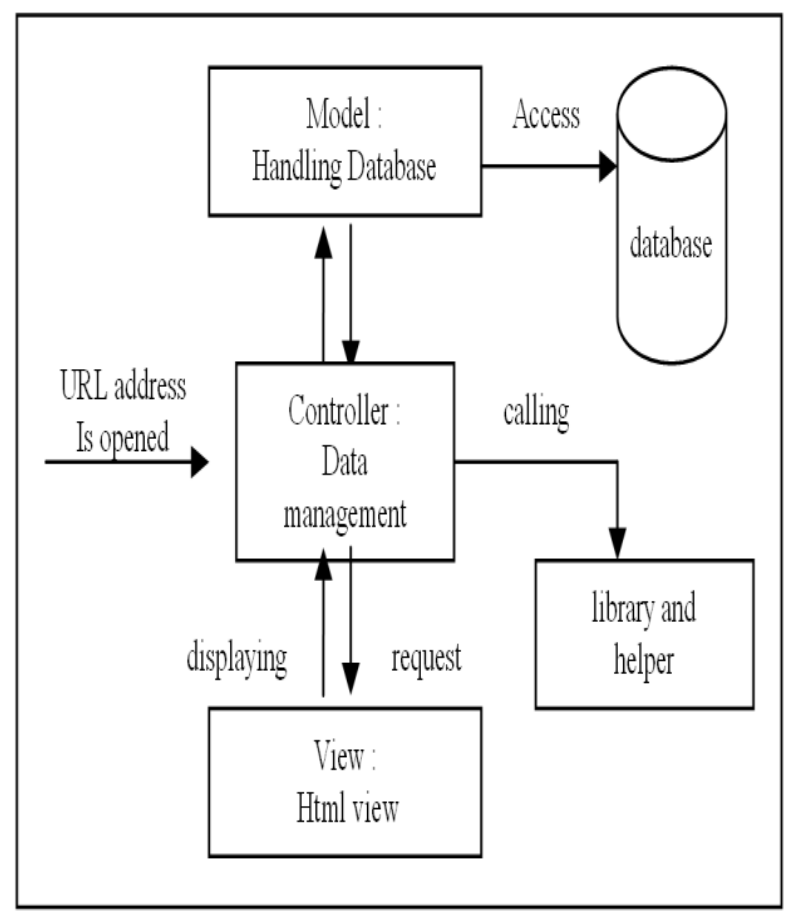

Fig 2: MVC Mechanism

Figure 2 shows the MVC working mechanism. When a URL is opened, the things that actually accessed are controller (located under controllers directory) and action (located inside the controller class). If required, along with the request, a set of variable and value pairs might be included. By default, if no controller is defined, the system will automatically redirect user to index controller and if the action is not exist, then the user will assume that the called action is index action. Though it is not mandatory, index action will render view named index.html to display to the user.

Different things will happen when the controller and action are defined and variable is sent. The variable will consider as data and receive proper treatment in the defined action in defined controller. While the data processing may require or relate to some underlying data in the database, controller may call corresponding models under the models directory. Calling to model objects required since the controller objects are not allowed to contain any database accessing codes. Therefore, any required data from database only available through model objects. Model objects contains specific functions that handle any database related operations. So, under the MVC working mechanism, every controller located under controllers directory and every actions held in controller render its own display based on views located under views directory.

\section{RESULT AND DISCUSSION 6.1 Result}

There are three users that allowed to access m-learning applications in the study, i.e. administrators, lecturer, and students. Every user has its own access rights. Table 1 shows the access rights of each user. 
Table 1. User Access Rights

\begin{tabular}{|c|c|c|c|}
\hline \multirow{2}{*}{ Access Rights } & \multicolumn{3}{|c|}{ User } \\
\hline & $\begin{array}{l}\text { Adminis } \\
\text { trator }\end{array}$ & Lecturer & Student \\
\hline User management & $\checkmark$ & - & - \\
\hline User's role management & $\checkmark$ & - & - \\
\hline Course management & $\checkmark$ & $\checkmark$ & - \\
\hline Enrollment & $\checkmark$ & $\checkmark$ & - \\
\hline Content management & $\checkmark$ & $\checkmark$ & \\
\hline Viewing content & $\checkmark$ & $\checkmark$ & $\checkmark$ \\
\hline $\begin{array}{l}\text { News/announcement } \\
\text { management }\end{array}$ & $\checkmark$ & $\checkmark$ & - \\
\hline $\begin{array}{c}\text { Viewing } \\
\text { news/announcement }\end{array}$ & $\checkmark$ & $\checkmark$ & $\checkmark$ \\
\hline Discussion management & $\checkmark$ & $\checkmark$ & - \\
\hline $\begin{array}{l}\text { Taking part in } \\
\text { disccussion }\end{array}$ & $\checkmark$ & $\checkmark$ & $\checkmark$ \\
\hline Assigment management & $\checkmark$ & $\checkmark$ & - \\
\hline $\begin{array}{l}\text { Reviewing and scoring } \\
\text { assignment submission }\end{array}$ & $\checkmark$ & $\checkmark$ & - \\
\hline Uploading assigment & $\checkmark$ & $\checkmark$ & $\checkmark$ \\
\hline $\begin{array}{l}\text { Examination } \\
\text { management }\end{array}$ & $\checkmark$ & $\checkmark$ & - \\
\hline $\begin{array}{l}\text { Viewing examination } \\
\text { score }\end{array}$ & $\checkmark$ & $\checkmark$ & - \\
\hline $\begin{array}{l}\text { Exam questions } \\
\text { management }\end{array}$ & $\checkmark$ & $\checkmark$ & - \\
\hline Following examination & $\checkmark$ & $\checkmark$ & $\checkmark$ \\
\hline
\end{tabular}

The m-learning application already brought online by uploading the necessary files to the hosting server. The $\mathrm{m}$ learning application supports three different views to maximize user experience, i.e. student view, teacher view and administrator view.

Student view is the view displayed for student users while accessing m-learning application. Students access the m- learning through mobile browser found on smart phones. First page that displayed to student that access the application is login page. In the login page, student user required to supply username and password to log into the system. Users who don't have account yet, may register to the system administrator. The student login page is shown in Figure 3.



Fig 3: Login Page

Students who have successfully logged in will go to the main page of the student. This page displays courses that currently followed by the student. Students are allowed to choose the available options, i.e. content, news, discussions, assignments, exams and exam results. Student may leave the system by clicking the logout button on the upper right corner. Main page and course option for students are shown in Figure 4.
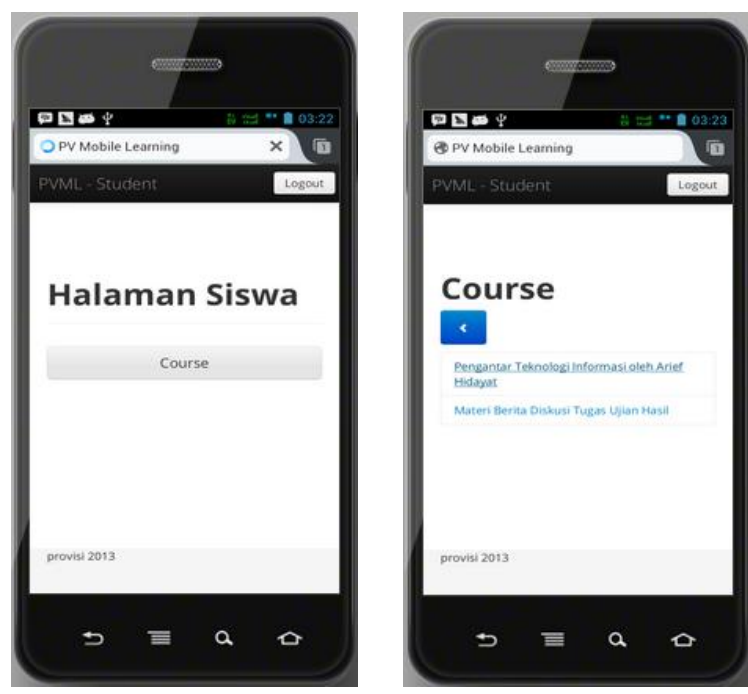

Fig 4: Student Main Page

Content page is a page that displays learning content in the PDF file format. Therefore, students can download and enjoy these contents, as shown in Figure 5. 


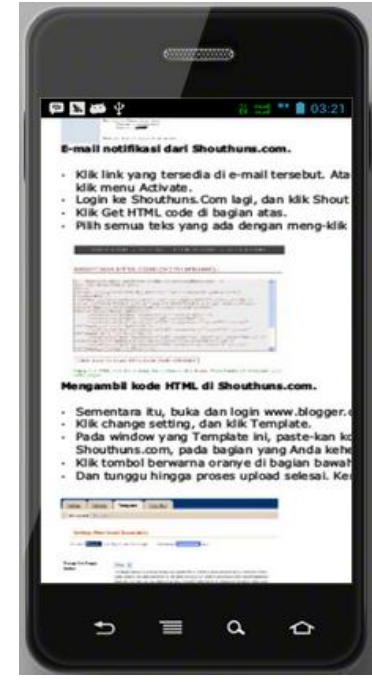

Fig 5: Content Page

Exam page displayed to student when a student take an exam. The supported questions format is in multiple-choice format, as shown in Figure 6.

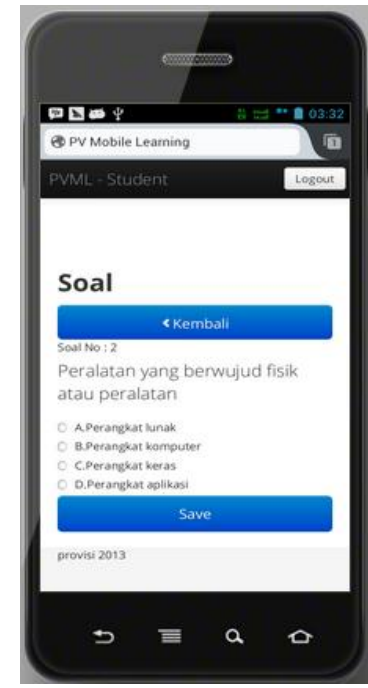

Fig 6: Exam Page

Teacher view is the view displayed to the teacher user to manage the course, such as students enrollment, upload the course content, create news/announcements, manage discussions, make assignments, manage exam, and review student exams results. Teacher users access the m-learning using mobile browser found in smart phones. Teacher users need to $\log$ in to the system to access the course management. Successfully logged in teacher user will be brought to teacher view main page. The page displays course that currently assigned to the teacher. The options available for the teacher are content, news, discussions, assignments, exams and exam results. Teacher user may leave the system by clicking the logout button on the upper right corner. Teacher view main page and available options can be seen in Figure 7.
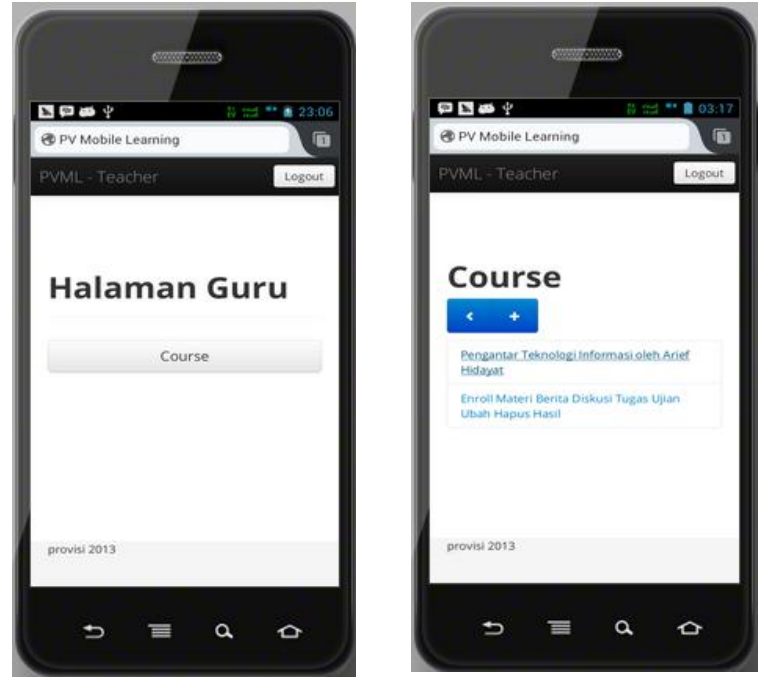

Fig 7: Teacher Main Page

Content upload page used by teachers to upload content in PDF file format. For each course, several contents may uploaded, usually correspond with chapter or topic in the course. Content upload page can be seen in Figure 8.

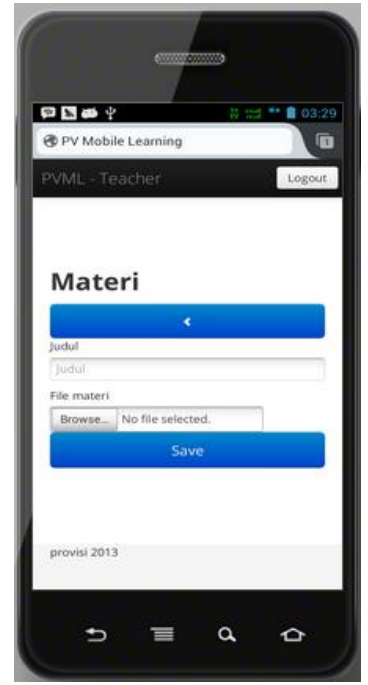

Fig 8: Content Upload Page

Administrator view is the view displayed to administrator user to manage user and course. Administrator users access the mlearning using mobile browser found on smart phones. Administrator users need to $\log$ in to access the system. Successfully logged in administrator user will be brought to administrator view main page. This page displays user management and course management. Administrator user may quit the system by clicking the logout button on the upper right corner. New user and new course page can be seen in Figure 9. 

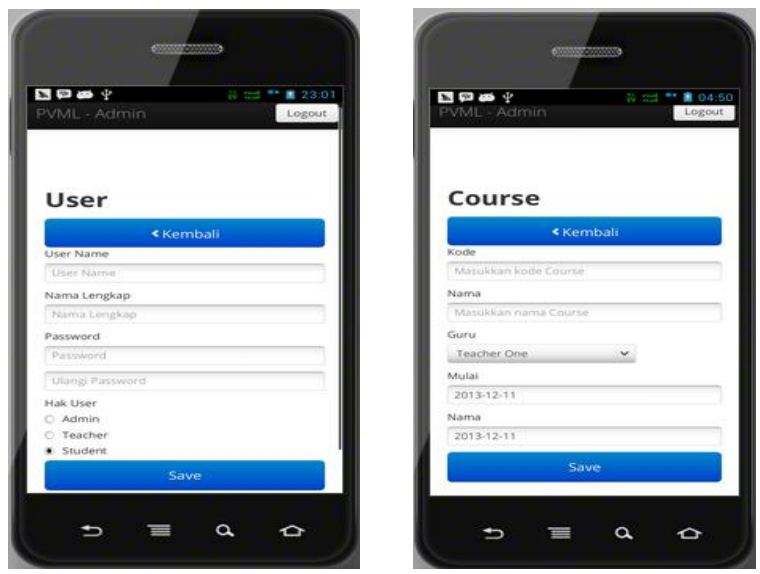

Fig 9: New User and New Course Page

New user page is used by the administrator user to register user who will access the m-learning. On this page, a specific role is assigned to the user, either as administrator, teacher or student. For each role, a set of access rights is given, as explained in the previous section. New course page used by administrator user to add a course that will be delivered in the $\mathrm{m}$-learning. Teacher assignment for the course is provided in the page as well.

\subsection{Discussion}

The discussion in this study is limited to some activities held by administrator, especially in course management, considering the number of existing functions. All of the mlearning application users need to log in first. In login process, system calls Check() action located in the login controller. The process includes validating the username and password, determine user role, and save user session. Authorized user is directed to the appropriate main page depends on its role.

Administrators have the rights to perform all the functions that exist in the m-learning application. Among of them are add new course, which will explained here. Like other function, add new course implemented using MVC programming technique with Code Igniter framework. After administrator user logged in successfully, system displays administrator main page. Administrator user need to click the course management. System call Index() action in course controller located in controllers/admin directory. Index() action renders view vcourselist located in views/admin directory. The view displays page that contains a list of courses.

After the page perfectly displayed, administrator user need to click the Add New Course button to add new course. System respond the request by calling NewCourse() action in course controller. NewCourse() action renders display vcoursedetail view. The view provides UI that required for supplying new course data.

Finish entering the data, administrator user need to click Save button to store the new course. System responds by calling the Save() action in course controller. Under the Save() action, system call InsertData() function in $m_{-}$courses located in models directory. The function contains the actual database operation that persist the data input by the user.

\section{CONCLUSION}

The use of the Code Igniter (CI) framework with model view controller (MVC) programming techniques speeds up the whole development process of mobile learning (m-learning) application. It is a result of separation of data persistence, logic and presentation. Further development will also be easier, due to the scalability of the framework, so the purpose of m-learning design to help the creation of mobile-based distance learning, as a concept of learning at any place and at any time, can be fully implemented. Developers need to focus only on the parts which will be developed under model-viewcontroller programming technique using Code Igniter framework.

Without framework, application improvement (e.g. protection against new hacking technique or compatibility to new technology) must be programmed manually. Using CodeIgniter, such improvement may be implemented in its future methods and functions. No manual work required unless upgrading the framework into a newer version.

CodeIgniter include numerous libraries and helpers which usually achieve the same functionality with less code. This will help the maintainable aspect of the application. It will also applied to the added feature in the future.

\section{ACKNOWLEDGMENTS}

Researchers would like to thank to the Ministry of Education and Culture - General Director of Higher Education (DIKTI) which provide fund for this research.

\section{REFERENCES}

[1] Hidayat A, Purwanto H. 2013. "Designing Application of M-Learning based on Content Management System". International Journal of Computer Applications 80(7):710, October 2013

[2] Trifonova A., Ronchetti M. 2003. A General Architecture for M-Learning. Technical Report DIT-03081, November 2003.

[3] Lehner F, Nosekabel H, Lehmann H. 2003. Wireless ELearning and Communication Environment: WELCOME at the University of Regensburg. E-Service Journal;2:2341.

[4] Vuksanovic, I.P and Sudarevic B. 2011. Use Of Web Application Frameworks in the Development of Small Applications. In Proceedings of MIPRO, the 34th International Convention.

[5] Ally M, Lin F, McGreal R, and Woo B. 2005. An Intelligent Agent for Adapting and Delivering Course Materials to Mobile Learners.Proceeding of the mLearn2005. 4th World Conference on Mlearning. Cape Town, South Africa.

[6] Ferl website. 2003. Introduction to Mobile Learning by Karen Wood. Available online: http://ferl.becta.org.uk/display.cfm?page $=65 \&$ catid $=192$ \&resid $=5194 \&$ printable $=1$ (accessed 09/04/12)

[7] Holzinger A, Nischelwitzer A, Meisenberger M. 2005. Mobile Phones as a Challenge for m-Learning : Experiences with the Mobile Learning Engine (MLE) using Mobile Interactive Learning Objects (MILOS).Proceeding PERCOMW '05. Third IEEE International Conference on Pervasive Computing and Communications Workshops. Washington DC, USA;307-311.

[8] Attewell, J. 2005. From Research and Development to Mobile Learning: Tools for Education and Training Providers and their Learners.Proceeding of the mLearn2005. 4th World Conference on Mlearning. Cape Town, South Africa.

[9] Sidik, B. 2012. Framework CodeIgniter. Bandung : Penerbit Informatika. 